\title{
Retraction Note to: Estimation of the source process and forward simulation of long-period ground motion of the 2018 Hokkaido Eastern Iburi, Japan, earthquake
}

\author{
Hisahiko Kubo ${ }^{1^{*}}$ (D, Asako Iwaki ${ }^{1}$, Wataru Suzuki ${ }^{1}$, Shin Aoi ${ }^{1}$ and Haruko Sekiguchi ${ }^{2}$
}

\section{Retraction to: Earth Palnets Space (2019) 71:98 https://doi.org/10.1186/s40623-019-1079-6}

The authors have retracted this article [1] because after its publication, they noticed that the source inversion was not done with the intended setting. Although it was mentioned in this article [1] that the rupture starting point of the fault model was set at the hypocenter determined by JMA as shown in Fig. 1, the rupture starting point in the real analysis was accidentally set at an incorrect location, the center point of the subfault southern neighbor of the hypocenter subfault. Thus, the source-inversion result (Figs. 2, 3, S1, and S2) and the forward ground-motion simulation result for the mainshock (Figs. 4 and 5), which used the source-inversion result as a source input, need to be corrected.

The authors have been given an opportunity to submit a corrected version. All authors agree to this retraction.
Reference

1. Kubo H, Iwaki A, Suzuki W, Aoi S, Sekiguchi H (2019) Estimation of the process and forward simulation of long-period ground motion of the 2018 Hokkaido Eastern Iburi, Japan, earthquake. Earth Planets Space 71:98. https://doi.org/10.1186/s40623-019-1079-6

\section{Publisher's Note}

Springer Nature remains neutral with regard to jurisdictional claims in published maps and institutional affiliations.

\author{
Author details \\ ${ }^{1}$ National Research, Institute for Earth Science and Disaster Resilience, 3-1 \\ Tennodai, Tsukuba, Ibaraki 305-0006, Japan. ${ }^{2}$ Disaster Prevention Research \\ Institute, Kyoto University, Gokasho, Uji, Kyoto 611-0011, Japan.
}

Published online: 23 December 2019

The original article can be found online at https://doi.org/10.1186/s4062 3-019-1079-6.

\footnotetext{
${ }^{*}$ Correspondence: hkubo@bosai.go.jp

${ }^{1}$ National Research, Institute for Earth Science and Disaster Resilience, 3-1

Tennodai, Tsukuba, Ibaraki 305-0006, Japan

Full list of author information is available at the end of the article
}

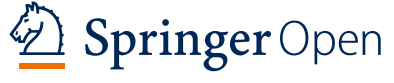

(c) The Author(s) 2019. This article is licensed under a Creative Commons Attribution 4.0 International License, which permits use, sharing, adaptation, distribution and reproduction in any medium or format, as long as you give appropriate credit to the original author(s) and the source, provide a link to the Creative Commons licence, and indicate if changes were made. The images or other third party material in this article are included in the article's Creative Commons licence, unless indicated otherwise in a credit line to the material. If material. is not included in the article's Creative Commons licence and your intended use is not permitted by statutory regulation or exceeds the permitted use, you will need to obtain permission directly from the copyright holder. To view a copy of this licence, visit http://creativecommons.org/licenses/by/4.0/ 